\title{
BUKU PAKET PENDIDIKAN AGAMA ISLAM SEKOLAH DASAR: Tinjauan terhadap Problematika Pemanfaatannya di Kota Gorontalo
}

\author{
Muhammad Sadli Mustafa \\ Balai Litbang Agama Makassar \\ Jl. A.P. Pettarani No. 72 Makassar \\ Email: muhammadsadlimustafa@gmail.com
}

\begin{abstract}
Abstrak:
Penelitian ini bertujuan untuk mengungkap seputar problematika pemanfaatan buku Pendidikan Agama Islam (PAI) di sekolah dasar di Kota Gorontalo dengan menggunakan metode penelitian kualitatif. Dua sekolah dasar negeri yang dijadikan sebagai sasaran penelitian ini dipilih secara purposive terdiri atas satu sekolah yang terkategori sebagai sekolah unggulan atau berprestasi, dan satu sekolah yang tidak terkategori unggulan atau berprestasi di Kota Gorontalo. Data dikumpulkan melalui teknik observasi, wawancara, dan dokumentasi. Hasil penelitian menunjukkan bahwa ketersediaan buku PAI masih sangat terbatas terutama untuk pegangan peserta didik baik kurikulum 2013 (K. 13) maupun Kurikulum Tingkat Satuan Pendidikan (KTSP). Mekanisme pemanfaatan buku PAI masih menggunakan cara klasik yakni dengan metode ceramah dan diskusi kelompok serta dengan memanfaatkan kelas dan mushalla dalam praktikum. Kendala lainnya yang dihadapi khususnya oleh peserta didik dari sisi materi adalah kesulitan mereka (khususnya kelas 1) pada materi yang menggunakan bahasa Arab pada K.13. Sementara tenaga pendidik (guru PAI) masih kesulitan dalam menerapkan K.13 karena belum ada sosialisasi K.13 khusus untuk mata pelajaran PAI SD.
\end{abstract}

\begin{abstract}
:
This study aims to reveal about the problematic use of Islamic Education (PAI) book in elementary school in Gorontalo city by using qualitative research method. Two of state primary schools targeted for this study were chosen purposively consisting of one school categorized as a pre-eminent school or achievement, and one unscientific or outstanding school in the city of Gorontalo. Data were collected through observation, interview, and documentation techniques. The results indicate that the availability of PAI books is still very limited, especially for grip learners both curriculum 2013 (K. 13) and Education Unit Level Curriculum (KTSP). Mechanism of utilization of book of PAI still use classical way that is by lecture method and group discussion and by utilizing class and mushalla in doing practicum. Obstacles encountered especially by learners from the material side are their difficulties (especially class 1) on materials that use Arabic in K.13. Educators (PAI teachers) are also still difficult in applying K.13 because there is no socialization K.13 specifically for subjects PAI SD.
\end{abstract}

Kata kunci:

Problematika, Pemanfaatan, Buku PAI SD, Kota Gorontalo

BEBERAPA tahun belakangan, di beberapa media baik media cetak, radio, televisi atau pun internet sering diberitakan mengenai aksi negatif banyaknya oknum pelajar baik yang terlibat aksi kekerasan dalam kelompok atau geng tertentu,tawuran antar pelajar, terjerat dalam dunia narkoba, sekumpulan pelajar yang pada jam-jam sekolah 
berada di pusat-pusat perbelanjaan dan keramaian, maupun aksi pelecehan seksual. Terakhir, biasa disaksikan melalui media televisi, aksi kekerasan geng motor yang melibatkan sekelompok pemuda yang masih berada pada usia sekolah (http://nasional.rimanews.com). Inilah potret sebagian pelajar saat ini. Aksi negatif seperti disebutkan seakan tidak pandang usia lagi bisa dilakukan oleh siapa saja termasuk anak usia SD. sebagai contoh, pernah diberitakan di salah satu media mengenai seorang anak SD di suatu daerah melakukan tindak kekerasan kepada seorang temannya yang mengakibatkan kematian (http://www.merdeka.com). Demikian juga, ada anak SD yang terlibat aksi pelecehan seksual terhadap rekannya sesama siswa SD (Metro TV, Metro Malam, 15 Oktober 2014).

Banyak faktor yang bisa memicu atau menyebabkan aksi-aksi negatif tersebut dilakukan oleh pelajar. Di antaranya, pengawasan yang kurang dari orang tua, pengaruh lingkungan, dan kurangnya pendidikan agama. Meski demikian, hal yang paling disorot tentunya adalah pendidikan agama. Sebab, fakta yang terjadi menunjukkan nilai-nilai moral belum melekat pada pribadi sebagian pelajar.

Ini mengindikasikan bahwa ada kelemahan dalam penyelenggaraan pendidikan agama Islam di sekolah yang belum tertutupi hingga saat ini. Salah satu di antara kelemahan itu menurut Atho' Mudzhar (dalam Muhaimin, 2005: 25-26) adalah terbatasnya sarana dan prasarana yang berakibat pada kecenderungan pengelolaan yang seadanya. Selain itu, buku paket pendidikan agama belum memadai dalam membangun kesadaran beragama, juga dalam mendorong perilaku bermoral dan berakhlak mulia peserta didik.

Senada dengan hal itu, dalam suatu penelitian yang telah dilakukan oleh peneliti Litbang Agama Makassar pada tahun 2014, juga menemukan bahwa keterbatasan buku penunjang pelajaran Pendidikan Agama di sekolah-sekolah (termasuk di perpustakaan sekolah) menjadi salah satu penyebab kurang maksimalnya pembelajaran PendidikanAgama Islam (As'ad dkk, 2009). Padahal dalam proses pembelajaran, buku menjadi aspek penting dalam meningkatkan pengetahuan peserta didik. Membaca dan memanfaatkan buku yang merupakan media dalam proses pembelajaran sedikit banyaknya memberi pengaruh pada sifat, sikap, dan pengetahuan peserta didik menjadi lebih baik (Mayusa, 2013: 13).

Mewujudkan manusia yang beriman dan bertakwa kepada Tuhan Yang Maha Esa dan berakhlak mulia adalah salah satu tujuan pendidikan nasional berdasarkan Undang-undang Republik Indonesia Nomor 20 Tahun 2003 tentang Sistem Pendidikan Nasional. Sejalan dengan itu, salah satu tujuan Pendidikan Agama Islam (PAI), sebagaimana dipahami dalam standar nasional pendidikan adalah untuk mewujudkan manusia yang beriman dan bertakwa kepada Allah SWT, berakhlak mulia, jujur, adil, disiplin, produktif, dan harmonis baik personal maupun social (BSNP, 2006: 5759). Hal ini tentu diharapkan dapat diwujudkan pada setiap jenjang pendidikan. Terutama pada tingkat sekolah dasar. Karena pada jenjang inilah tempatnya untuk menanamkan pondasi agama dengan kuat.

Salah satu yang dibutuhkan dalam mewujudkan tujuan tersebut, adalah ketersediaan sumber belajar dalam hal ini buku yang merupakan komponen penting da- 
lam mendukung proses pembelajaran pendidikan agama di sekolah dasar. Apalagi saat ini, di beberapa sekolah dasar ada yang menerapkan kurikulum 2006 dan ada pula yang menerapkan kurikulum 2013.Buku dimaksud adalah buku paket pelajaran PAI yang dapat digunakan sebagai bahan ajar pokokatau pendukung pembelajaran sesuai dengan kebutuhan pembelajaran (Supriadi, 2000: 1-2). Selain itu, tentu dibutuhkan kesiapan dari pihak sekolahdan tenaga pendidik khususnya guru PAI untuk memasilitasi dan memanfaatkan buku PAI yang ada.

Oleh karena itu, penelitian ini dilakukan untuk mengungkap problematika pemanfaatan buku Pendidikan Agama Islam Sekolah Dasar di Kota Gorontalo. Khususnya terkait dengan ketersediaannya, mekanisme pemanfaatannya dan problem yang dihadapi oleh pendidik dan peserta didik dalam memanfaatkan buku PAI di Sekolah Dasar di Kota Gorontalo.

Penelitian inifokus menelusuri hal-hal yang menjadi problematika pemanfaatan buku paket PAI di sekolah dasar. Diawali dengan identifikasi buku-buku paket PAI yang tersedia dan yang dibutuhkan oleh tenaga pendidik dan dan peserta didik di sekolah dasar. Langkah selanjutnya adalah penelusuran terhadap cara memanfaatkan buku-buku tersebut dan kendalayang dihadapi serta distribusi dan pengadaan buku tersebut di sekolah-sekolah.

Pemanfaatan berarti cara, proses, atau perbuatan memanfaatkan (Depdiknas, 2008: 873). Adapun buku paket PAI yang dimaksud adalah buku teks pelajaran yang merupakan pegangan tenaga pendidik dan peserta didik dalam pembelajaran PAI berdasarkan kurikulum yang ditetapkan di sekolah sasaran penelitian termasuk buku-buku PAI yang tersedia di perpustakaan sekolah. Buku teks terbagi atas buku pelajaran pokok yang disediakan oleh pemerintah dan buku pelajaran pelengkap. Buku pelajaran pelengkap adalah buku-buku terbitan swasta yang dibeli oleh sekolah atau pendidik atau peserta didik (Supriadi, 2000: 1-2).

Penelitian ini merupakan penelitian deskriptif kualitatif. Data dikumpulkan dengan teknik observasi, wawancara dan studi dokumen sebagaimana lazimnya digunakan dalam penelitian kualitatif (Sugiyono, 2010). Data yang dikumpulkan selama penelitian, dianalisis secara terus menerus sampai tuntas sehingga data jenuh (Miles and Huberman, 1984).

Penelitian ini dilaksanakan di Kota Gorontalo Provinsi Gorontalo. Sekolah dasar negeri yang dijadikan sasaran penelitian yakni satu sekolah yang terkategori sebagai sekolah unggulan, dan satu sekolah yang tidak terkategori unggulan di Kota Gorontalo. Pertimbangan pemilihan dua sekolah dasar negeri itu didasarkan pada tingkatan akreditasi, dan prestasi sekolah menurut kebijakan pemerintah setempat dengan metode purposive.

\section{HASIL PENELITIAN DAN PEMBAHASAN}

\section{Gambaran Umum Sekolah Dasar (SD) di Kota Gorontalo}

Penduduk Kota Gorontalo tercatat berjumlah 186.299 jiwa pada tahun 2014 (Kementerian Agama Kota Gorontalo, 2014). Penduduk yang berusia antara 5 - 9 tahun 
berkisar 17.000 jiwa. Sedangkan penduduk yang berusia antar 10 - 14 tahun berkisar 18.000 jiwa (BPS Kota Gorontalo, 2014: 51). Artinya bahwa jumlah anak usia sekolah di bawah 14 tahun (SMP dan SD) berkisar 35.000. Jumlah ini berbanding lurus dengan jumlah institusi/lembaga pendidikan khususnya pada tingkat dasar (SD) se-Kota Gorontalo yang tersebar di 9 (Sembilan) kecamatan, yakni tercatat 117 buah SD pada tahun 2014 (Dinas Pendidikan Kota Gorontalo, 2014 \& Kementerian Agama Kota Gorontalo, 2014).

Kota Gorontalo merupakan kota yang penduduknya mayoritas muslim. Penduduk Gorontalo yang beragama Islam sebanyak 175.877 (94,4\%), 7426 (3,99\%), beragama Kristen, 1846 (0,99\%) beragama Katholik, 352 (0,19\%) beragama Hindu, 793 $(0,42 \%)$ beragama Budha, 5 (0,003\%) beragama Konghuchu (Kementerian Agama Kota Gorontalo, 2014). Dengan banyaknya jumlah penduduk yang beragama Islam ditambah dengan banyaknya anak usia sekolah di tingkat dasar menunjukkan bahwa masyarakat Kota Gorontalo membutuhkan pendidikan agama Islam untuk anak-anak mereka yang disekolahkan di SD yang ada di Kota Gorontalo. Banyaknya peserta didik tingkat SD menyebabkan sebagian besar SD membuka kelas paralel. Sehingga terdapat 886 rombongan belajar (rombel) dari 117 SD yang ada di Kota Gorontalo. Meski demikian, banyaknya jumlah SD dan rombel yang ada tidak sebanding dengan jumlah guru Pendidikan Agama Islam (PAI) yang ada. Sebab, ada sejumlah SD yang tidak memiliki guru PAI (Kementerian Agama Kota Gorontalo, 2014 \& Dinas Pendidikan Kota Gorontalo, 2014). Jumlah guru PAI SD se-Kota Gorontalo saat ini adalah 118 orang. 106 di antaranya merupakan Pegawai Negeri Sipil (PNS). Sedangkan sisanya, 12 orang, merupakan tenaga honorer. Menurut Suryani Makalalang dan Syaiful (Staf Seksi PAI Kemenag Kota Gorontalo, wawancara, 25 Februari 2015), bahwa setiap tahun jumlah guru PAI semakin berkurang karena banyak yang sudah memasuki masa pensiun sementara dalam beberapa tahun terakhir belum ada pengangkatan tenaga pendidik untuk PAI di SD. Bila keadaan ini berlanjut terus diperkirakan hingga tahun 2017-2018 jumlah guru PAI akan berkurang hingga 50\% dari jumlah yang ada sekarang. Bahkan, jumlah pengawas PAI SD pun lebih tidak proporsional lagi. Sebab, pengawas PAI SD yang ada saat ini hanya tersisa 2 (dua) orang saja. Sementara seorang di antaranya akan memasuki masa pensiun di tahun 2016. Berarti tersisa tinggal 1 (satu) orang saja pengawas PAI SD di tahun 2016 bila tak kunjung ada pengangkatan pengawas PAI SD. Kondisi ini tentu memprihatinkan untuk pembelajaran PAI SD. Sebab, usia SD-lah merupakan masa sangat penting untuk menanamkan nilai-nilai agama dan budi pekerti sehingga kelak anak-anak tersebut memiliki landasan moral ketika dewasa.

Terkait dengan status negeri dan swasta, SD yang berstatus negeri di Kota Gorontalo jumlahnya jauh lebih banyak dibandingkan SD yang berstatus swasta. Jumlah SD yang berstatus negeri sebanyak 108 buah termasuk sebuah SLB di Kecamatan Dungingi. Sedangkan sisanya sebanyak 9 buah berstatus swasta. Dari 108 buah Sekolah Dasar Negeri (SDN) tersebut, sebanyak 40 SDN terakreditasi A, 60 SDN terakreditasi B, dan 8 SDN terakreditasi C. Sedangkan dari 9 SD swasta yang ada, baru satu yang 
terakreditasi A, 4 (empat) terakreditasi B, dan sisanya belum terakreditasi (Dinas Pendidikan Kota Gorontalo, 2014 \& BAP Gorontalo, 2014).

Menurut Djiuma (Kasi SD/SMP Dinas Pendidikan Kota Gorontalo, wawancara, Rabu 25 Februari 2015), dari 107 buah SDN se-Kota Gorontalo, ada dua buah di antaranya yang berprestasi yakni SDN 30 dan SDN 46. Kedua SDN tersebut pernah menjuarai event Olimpiade Sains tingkat SD se-Provinsi Gorontalo dan mewakili Provinsi Gorontalo pada event yang sama di tingkat nasional. Di antara kedua SDN tersebut yang memiliki paling banyak peserta didik adalah SDN 30 Kota Selatan. Artinya bahwa tingkat antusiasme masyarakat menyekolahkan anak mereka di SD ini lebih besar. Ini dapat dijadikan sebagai indikator bahwa sekolah ini dianggap lebih unggul di mata masyarakat. Sebaliknya SDN yang dianggap kurang berprestasi dibanding SDN lainnya adalah SDN 7 Kota Barat. Sekolah ini dianggap oleh Suryani Makalalang, pengawas PAI SD/MI, lambat perkembangannya. Bahkan, tergolong sekolah yang kurang tertata dengan baik administrasi dan sarana prasarananya.

Berdasarkan keterangan tersebut maka SDN yang menjadi sasaran penelitian ini adalah SDN 30 Kota Selatan dan SDN 7 Kota Barat.

\section{Profil Singkat Sekolah Dasar Sasaran}

\section{SDN 30 Kota Selatan}

Sekolah ini terletak di Jalan Jaksa Agung Suprapto Nomor 9, Kelurahan Limba U 2, Kecamatan Kota Selatan, Kota Gorontalo Provinsi Gorontalo.

Sekolah ini didirikan pada tahun 1961. Sekolah ini berada di atas lahan seluas $5850 \mathrm{~m}^{2}$ milik pemerintah Kota Gorontalo. Sarana prasarana sekolah ini sangat memadai. Di sekolah ini terdapat 24 buah ruang belajar. Ruang kepala sekolah cukup luas berdempetan dengan ruang guru dan staf yang menyatu dalam sebuah gedung kantor. Sekolah ini juga memiliki sebuah ruang laboratorium bahasa, sebuah gedung perpustakaan, sebuah ruang koperasi, sebuah ruang UKS, sebuah aula, dan sebuah mushalla. Juga terdapat 10 buah wc dan 3 (tiga) buah kamar mandi. Terdapat dua buah ruang terbuka yang terletak di depan gedung sekolah dan di antara gedung kelas berbentuk "U". Bangunan sekolah seluruhnya seluas $1800 \mathrm{~m}^{2}$. Di belakang bangunan gedung sekolah terdapat beberapa warung yang menjual aneka jajanan. Warung tersebut dapat diakses dengan sangat mudah oleh para peserta didik karena masih berada dalam tembok pagar lingkungan sekolah.

Sebelum bernama SDN 30, sekolah ini sesungguhnya dikenal dengan nama SDN 61 (Badriyah Podu, Guru PAI, wawancara 27 Februari 2015). SDN 30 saat ini merupakan gabungan (re-group) dari beberapa sekolah dasar di Kota Selatan. Sekolah dasar dimaksud adalah SDN 55, SDN 58, SDN 59, SDN 60, DAN SDN 61. Penggabungan tersebut merupakan implementasi dari Surat Keputusan Walikota Gorontalo Nomor 1316 Tahun 2005 Tentang Penetapan Kembali Nomenklatur Sekolah Dasar Negeri (SDN) di Kota Gorontalo (selanjutnya disebut SK Walikota Gorontalo tahun 2005). Sejak saat itulah, tempat di mana SDN 61 dahulu berdiri kini dikenal sebagai SDN 30 Kota Selatan. 
Pada tahun 2007 hingga 2010, SDN 30 sempat dijadikan sebagai RSBI atau Rintisan Sekolah Bertaraf Internasional (Hadijah Mootinelo, Kepala Sekolah SDN 30, wawancara, senin 2 Maret 2015). Kemudian pada tanggal 16 Januari 2015, SDN 30 ditetapkan oleh Disdik setempat sebagai salah satu dari 12 sekolah dasar yang menjadi sekolah sasaran atau pilot project dalam penerapan Kurikulum 2013. Sebelas sekolah dasar lainnya yang merupakan pilot project penerapan Kurikulum 2013 adalah SDN 17 Kota Barat, SDN 24 Dungingi, SDN 33 Kota Selatan, SDN 46 Hulonthalangi, SDN 61 Kota Timur, SDN 77 Kota Tengah, SDN 80 Kota Tengah, SDN 82 Kota Tengah, SDN 85 Kota Tengah, SDN 93 Sipatana dan SDN 102 Kota Utara (Dinas Pendidikan Kota Gorontalo, 2015).

Sebagai pilot project, di sekolah ini diterapkan 2 (dua) jenis kurikulum. Yakni kurikulum 2006 (KTSP) diterapkan di kelas 3 (tiga) dan kelas 6 (enam). Sedangkan kurikulum 2013 (K.13) diterapkan di kelas 1 (satu), kelas 2 (dua), kelas 4 (empat), dan kelas 5 (lima).

Sekolah ini sudah terakreditasi A dengan nilai 91,57 sejak 18 Oktober 2010 (BAP Kota Gorontalo, 2014). Sekolah ini dikenal sebagai sekolah yang memiliki cukup banyak prestasi. Tercatat sejak tahun 1991 hingga tahun 2014 sudah puluhan kali sekolah ini meraih prestasi baik dalam event akademik maupun non akademik. Di ruang kantor sekolah ini terpajang puluhan trofi dan sertifikat tanda prestasi yang telah diraih. Terakhir, sekolah ini sempat mewakili Provinsi Gorontalo dalam event Olimpiade Sains Nasional tahun 2014 (Wawan, Staf Dinas Pendidikan Kota Gorontalo, Rabu 25 Februari 2015). Bahkan, dari sisi kinerja lembaga, sekolah ini mendapatkan predikat "sekolah dengan kinerja terbaik" se-Provinsi Gorontalo. Selanjutnya, sekolah ini mewakili Provinsi Gorontalo pada event sekolah berprestasi tingkat nasional yang dilaksanakan oleh Kementerian Pendidikan dan Kebudayaan (Kemendikbud) Tahun 2014 di Yogyakarta dan berhasil meraih peringkat III (ketiga). Pada waktu yang bersamaan sekolah ini juga meraih prestasi sebagai sekolah berprestasi di bidang PAI seProvinsi Gorontalo. Namun, ketika diminta oleh Kementerian Agama Provinsi Gorontalo untuk mewakili provinsi pada event sekolah berprestasi di bidang PAI yang dilaksanakan oleh Kementerian Agama di Bali, urung diikuti. Sebab, waktu kegiatannya bersamaan dengan event yang dilaksanakan oleh Kemendikbud sebagaimana telah disebutkan. Selain itu, sekolah ini juga merupakan sekolah binaan Kementerian Agama.

Tercatat, ada 32 orang tenaga pendidik yang bertugas di sekolah ini. 29 orang di antaranya merupakan PNS. Sedangkan 3 (tiga) lainnya adalah tenaga honorer. Dari 29 PNS tersebut baru 16 orang (termasuk kepala sekolah dan semua Guru PAI) yang telah sertifikasi. Sedangkan 13 orang lainnya dan semua guru honor belum sertifikasi. Dari keseluruhan tenaga pendidik tersebut (PNS maupun tenaga honor), 20 orang di antaranya berkualifikasi sarjana. 7 (tujuh) orang tamatan sekolah keguruan setingkat SMA. 2 (dua) orang tamatan diploma (D.2). Sedangkan seorang lainnya adalah magister (S.2). Adapun Guru PAI di sekolah ini berjumlah 4 (empat) orang. 3 (tiga) orang PNS dan seorang tenaga honorer. Kualifikasi keempat guru PAI tersebut semuanya adalah Sarjana Pendidikan Islam. 
Jumlah peserta didik tahun pelajaran 2014 - 2015 tercatat sebanyak 620 orang yang tersebar di 21 rombel. Peserta didik Kelas 1 (satu) sebanyak 126 orang terbagi dalam 4 (empat) rombel. Kelas 2 (dua) sebanyak 133 orang terbagi dalam 4 (empat) rombel. Kelas 3 (tiga) sebanyak 94 orang terbagi dalam 3 (tiga) rombel. Kelas 4 (empat) sebanyak 95 orang terbagi dalam 3 (tiga) rombel. Kelas 5 (lima) sebanyak 89 orang terbagi dalam 3 (tiga) rombel. Dan Kelas 6 (enam) sebanyak 83 orang terbagi dalam 4 (empat) rombel.

Peserta didik yang bersekolah di tempat ini mayoritas muslim. Dari 620 peserta didik yang ada, 596 orang $(96,13 \%)$ di antaranya adalah muslim, 19 orang (3,06\%) beragama Kristen, 4 (empat) orang (0,65\%) beragama Katholik, dan sisanya, 1 (satu) orang $(0,16 \%)$ beragama Budha.

\section{SDN 7 Kota Barat}

Sekolah ini terletak di Jalan Usman Isa, Kelurahan Pilolodaa, Kecamatan Kota Barat, Kota Gorontalo Provinsi Gorontalo.

Sekolah ini didirikan pada tahun 1975. Berdiri di atas lahan milik pemerintah kota seluas $2057 \mathrm{~m}^{2}$ dengan sarana prasarana yang cukup memadai. Saat didirikan, sekolah ini bernama SDN 10 Kota Barat. Pada saat itu, regulasi menghendaki urutan nomor SDN berdasarkan wilayah kecamatan. Kemudian berganti nama menjadi SDN 7 Kota Barat berdasarkan SK Walikota Gorontalo tahun 2005 sebagaimana juga dialami SDN 30 Kota Selatan. Di mana dalam regulasi tersebut diatur tentang perubahan nama SDN bukan lagi diurut berdasarkan kecamatan tetapi perkota (Nico, Mahmud, Kepala Sekolah SDN 7, wawancara, Selasa 3 Maret 2015).

Sekolah yang agak kurang prestasinya dibanding sekolah lainnya itu adalah SDN 7, pak. Dulu, sekolah itu tidak tertata dengan baik bangunan dan halamannya. Tetapi sekarang sudah mulai ada peningkatan setelah dua kali berganti kepala sekolah.

Demikian petikan kalimat yang diungkapkan oleh salah seorang pengawas SD di Kota Gorontalo. Ini kemudian membuat penulis semakin tertarik untuk melihat sekolah ini. Bayangan penulis sebelum sampai di sekolah ini adalah bahwa sekolah ini bangunan dan halamannya "kumuh". Namun, setelah berada di sekolah bersangkutan, apa yang terbayangkan itu sirna seketika karena ternyata sekolah ini sudah tertata demikian rapi dan cukup indah. Kesan "kumuh" tak terlihat sama sekali.

Setelah bertemu dan berbincang dengan kepala sekolah, didapatkan keterangan bahwa memang dahulu sekolah ini kurang maju. Bahkan, pernah mendapatkan predikat buruk terkait dengan tata kelola lembaga pendidikan. Predikat sebagai "sekolah dengan kinerja terburuk" disematkan pada tahun 2010 oleh Dinas Pendidikan (Disdik) Kota Gorontalo (Nico Mahmud, wawancara, Sabtu 7 Maret 2015). Sekolah mulai dibenahi setelah pimpinan sekolah berganti dua kali. Dan saat ini dipimpin oleh Nico Mahmud, S. Pd. Menurut Rahmat (wawancara, Sabtu 7 Maret 2015), kepala sekolah yang disebut terakhir inilah yang membawa perubahan signifikan terhadap tata kelola SDN 7 ini. Ia merupakan salah seorang kepala sekolah berprestasi di Kota Gorontalo. 
Sekolah ini terletak persis di kaki perbukitan di antara pemukiman penduduk dan beberapa kantor. Di bagian utara yang merupakan bagian depan atau gerbang sekolah berbatasan dengan lorong Jalan Loji, Kantor Kelurahan Pilolodaa, Kantor Koramil dan Kantor KUA Kecamatan Kota Barat. Bagian timur atau bagian samping kanan sekolah berbatasan dengan Jalan Usman Isa yang dapat tembus menuju tempat wisata permandian Bakpotana. Bagian selatan atau di bagian belakang bangunan dan lingkungan sekolah berbatasan dengan pemukiman masyarakat. Bagian barat atau bagian samping kiri sekolah berbatasan dengan Kantor Polsek Kota Barat.

Tingkat akreditasi sekolah ini berada pada level "C" (Nico, Mahmud, Kepala Sekolah SDN 7, wawancara, Selasa 3 Maret 2015). Yang menarik dari akreditasi ini adalah bahwa di data sekolah se-Kota Gorontalo yang tercatat di Disdik Kota Gorontalo, sekolah ini terakreditasi " $\mathrm{D}$ ”. suatu tingkat akreditasi yang tidak dikenal oleh Badan Akreditasi Provinsi (BAP) Gorontalo. Ketika dikonfirmasi kembali dengan pihak Disdik seksi SD hanya dikatakan "seperti itu yang kami terima dari sekolah, pak". Sementara oleh pihak BAP Gorontalo seksi informasi dan penataan/teknisi dikatakan bahwa "mungkin itu hanya salah ketik, pak". Sedangkan ketika di tanyakan langsung ke pihak SDN 7 dalam hal ini kepala sekolah dan salah seorang stafnya, mereka mengaku bahwa sekolah tersebut terakreditasi " $C$ " tetapi ketika diminta untuk memperlihatkan sertifikat akreditasinya ternyata sertifikatnya tidak ada. Mereka mengaku hanya mendapatkan informasi itu secara lisan dari pihak Disdik Kota Gorontalo. Rahmat (wawancara Sabtu 7 Maret 2015), menambahkan bahwa pihak BAP akan memproses lagi akreditasi sekolah ini. Namun, sampai saat ini belum dilakukan visitasi karena masih perlu melengkapi atau memperbaiki berkas atau data yang dibutuhkan. Keadaan ini mengindikasikan kurangnya koordinasi antara pihak BAP, Disdik, dan sekolah terkait. Sehingga terjadi perbedaan dalam hal tingkat akreditasi sekolah ini yang tercatat di masing-masing instansi tersebut.

Tenaga pendidik di sekolah ini terakhir tercatat berjumlah 14 orang. 11 orang PNS dan 3 (tiga) orang lainnya merupakan tenaga honorer. Dari sebelas PNS tersebut baru 8 (delapan) orang di antaranya sudah sertifikasi termasuk kepala sekolah dan seorang Guru PAI. Sedangkan guru honor yang ada belum sertifikasi. Kualifikasi pendidikan mereka cukup beragam. Dari 14 orang guru yang bertugas di sekolah ini 9 (sembilan) di antaranya merupakan sarjana pendidikan. 4 (empat) berkualifikasi D.2. Sedangkan seorang lainnya merupakan tamatan sekolah keguruan setingkat SMA. Tenaga pendidik untuk Pendidikan Agama Islam hanya 2 (dua) orang. Salah seorang di antaranya adalah PNS dengan kualifikasi D.2 PAI. Sedangkan seorang lainnya adalah tenaga honorer dengan kualifikasi Sarjana.

Peserta didik di sekolah ini berjumlah 240 orang yang tersebar di 10 rombel. Kelas 1 (satu) berjumlah 39 orang terbagi dalam 2 (dua) rombel. Kelas 2 (dua) berjumlah 42 orang terbagi dalam 2 (dua) rombel. Kelas 3 (tiga) berjumlah 42 orang terbagi dalam 2 (dua) rombel. Kelas 4 (empat) berjumlah 44 orang terbagi dalam 2 (dua) rombel. Kelas 5 (lima) berjumlah 36 orang. Kelas 6 (enam) berjumlah 37 orang. Kelas 5 (lima) dan kelas 6 (enam) masing-masing hanya 1 rombel. Mayoritas peserta didik ter- 
sebut tergolong masyarakat ekonomi lemah. Bahkan, sekitar 160 orang di antaranya termasuk peserta didik yang pernah menerima Bantuan Siswa Miskin (BSM) (Nico, Mahmud, Kepala Sekolah SDN 7, wawancara, Selasa 3 Maret 2015).

\section{Potret Buram Ketersediaan Buku PAI di Sekolah Dasar}

"Sangat kurang", "tidak mencukupi". Kalimat ini yang selalu muncul ketika ditanyakan mengenai ketersediaan buku di sekolah dasar. Baik ketika ditanyakan kepada guru PAI, kepala sekolah, pengawas PAI maupun ketika ditanyakan kepada pengurus kelompok kerja guru. Jangankan buku PAI, buku pelajaran umum pun terkadang demikian. Hanya saja, buku pelajaran umum nasibnya sedikit lebih baik ketimbang buku PAI. Sebagai contoh, pengadaan buku melalui dana BOS di SDN 7 Kota Barat misalnya, buku PAI hanya disediakan untuk pegangan Guru PAI masingmasing 1 buku perkelas. Tak ada satupun buku PAI yang dianggarkan untuk peserta didik (Zuriyati, Guru PAI SDN 7, wawancara, Sabtu 7 Maret 2015).

Ketersediaan buku khususnya buku PAI memang menjadi kendala besar dalam proses pembelajaran PAI tak terkecuali di Kota Gorontalo. Pengadaan buku PAI hanya mengandalkan dana Bantuan Operasional Sekolah (BOS) yang jumlahnya juga dibatasi yakni tak lebih dari 5\% dari anggaran yang ada. Sementara buku yang dibutuhkan di sekolah bukan hanya buku PAI tetapi buku untuk semua mata pelajaran. Sehingga untuk mengakomodir semua mata pelajaran yang ada dengan dana yang sangat terbatas dalam pengadaannya menjadi tidak maksimal (Hadijah Mootinelo, Kepala Sekolah SDN 30, wawancara, Sabtu 7 Maret 2015). Sementara jika hanya berharap pengadaan dari pemerintah tentu butuh waktu cukup lama dan juga tak jelas kapan pengadaannya.

Terkait dengan ketersediaan buku PAI pada sekolah dasar di Kota Gorontalo memang masih sangat memprihatinkan. Dari seratus lebih sekolah dasar yang ada, ketersediaan buku PAI menjadi kendala tersendiri yang belum juga terselesaikan hingga sekarang baik di sekolah dasar yang dikenal cukup maju atau pernah mendapatkan predikat sekolah dengan kinerja terbaik maupun di sekolah dasar lainnya yang memiliki prestasi sebaliknya. Ketersediaan buku PAI semakin menjadi problem apabila sekolah dasar memiliki peserta didik dalam jumlah yang banyak atau memiliki rombel yang lebih banyak.

Di SDN 30 Kota Selatan misalnya, yang merupakan sekolah yang maju dan berprestasi atau yang menjadi unggulan di Kota Gorontalo dan memiliki 21 rombel, "kewalahan" dalam menyediakan buku PAI untuk 620 peserta didiknya. Sehingga untuk mengantisipasi kendala tersebut Guru PAI menganjurkan kepada murid-muridnya untuk mengkopi buku PAI yang ada. Atau meminta kesediaan orangtua murid untuk membelikan buku untuk anaknya yang bersekolah di SDN 30. Satu hal yang cukup menggembirakan bagi Guru PAI adalah bahwa pada umumnya mereka bersedia melengkapi kebutuhan anak-anak mereka khususnya dalam hal menyediakan buku PAI baik dengan membeli maupun dengan menfoto kopi buku yang ada. Meski demikian, masih ada sebagian dari mereka yang tidak sanggup melakukannya karena keterbatasan ekonomi orang tua. 
Hal lain yang juga menjadi kendala adalah bahwa toko buku yang ada di Kota Gorontalo jumlahnya bisa dihitung jari. Di antaranya Ramedia dan Gramedia. Itu pun, jumlah buku yang dijual untuk kebutuhan murid sekolah dasar termasuk buku PAI jumlahnya terbatas. Buku PAI K.13 tidak tersedia sama sekali. Hanya buku PAI KTSP yang tersedia, itupun beberapa eksemplar saja. Padahal, dibandingkan jumlah anak yang bersekolah di 100 lebih sekolah dasar di Kota Gorontalo yang menggunakan KTSP, jumlah buku yang tersedia tersebut tentu sangat tak seimbang.

Hal yang kurang lebih sama juga terjadi di Perpustakaan Daerah Provinsi Gorontalo dan Perpustakaan daerah Kota Gorontalo. Demikian pula yang halnya di perpustakaan sekolah dasar. Di perpustakaan SDN 30 misalnya, meski cukup banyak tersedia buku PAI hingga lebih dari 300 eksemplar. Namun, buku-buku tersebut adalah buku-buku lama yang tidak terpakai lagi. Sehingga sedikitpun tak tersentuh oleh peserta didik meski mereka biasa memanfaatkan perpustakaan untuk membaca atau belajar ketika jam isterahat tiba. Naswa, murid kelas 6 SDN 30, mengungkapkan alasannya tidak meluangkan waktu untuk membaca buku PAI yang tersedia tersebut adalah karena; "buku agama yang itu so lama, tidak dipake lagi" (naswa, wawancara, Senin 2 Maret 2015). Padahal, dalam Permendiknas tahun 2005 Pasal 8 Ayat 4 diamanahkan bahkan diwajibkan agar setiap sekolah menyediakan paling sedikit 10 buku untuk setiap mata pelajaran untuk setiap kelas untuk membantu peserta didik yang tidak mampu memiliki buku pelajaran. Yang lebih memprihatinkan lagi terjadi di SDN 7 Kota Barat. Perpustakaan sekolah di SDN 7 ini sangat tidak layak. Sebab, selain digunakan juga sebagai ruang kelas. buku-buku yang ada sangat tidak tertata dan terawat dengan baik. Bahkan, Buku PAI tak tersedia. Hanya ada 2 (dua) jenis buku terkait PAI yang terdapat di perpustakaan, yaitu buku pegangan guru dan buku bimbingan pesantren kilat untuk peserta didik tingkat SD. Itupun, terbitan tahun 1999. Yang lebih mencengangkan lagi, menurut penuturan Guru PAI di sekolah tersebut bahwa hanya guru PAI yang memiliki buku PAI. Hanya satu di antara murid-murid sekolah dasar tersebut yang memiliki buku PAI. Hal itu, disebabkan karena pada umumnya murid-murid yang bersekolah di SDN 7 ini berasal dari warga dengan keadaan ekonomi lemah. Bahkan, untuk mengakses buku-buku penunjang, dan buku-buku terbaru guru PAI hanya meminjam dari sekolah lainnya untuk difotokopi. Belum pernah ada distribusi buku PAI di sekolah ini sejak kurikulum berganti dari kurikulum berbasis kompetensi (KBK) ke KTSP hingga ke K. 13. Hanya sekali saja pernah ada pengadaan buku PAI yang didistribusikan olehKementerian Agama yaitu pada tahun 1980-an. Sesudah itu, tak pernah lagi ada pengadaan dan distribusi buku PAI dari pemerintah ke SDN 7 hingga sekarang (Zuriyati,Guru PAI, wawancara Sabtu 7 Maret 2015).

Hal yang cukup memprihatinkan justru terjadi di SDN 30 Kota Selatan. Sebagai sekolah sasaran/pilot project K. 13, sekolah ini memberlakukan dua jenis kurikulum, yakni K. 13 untuk kelas 1 (satu), 2 (dua), 4 (empat), dan 5 (lima), dan KTSP untuk kelas 3 (tiga) dan kelas 6 (enam). Namun, sekolah ini justru tidak disuplai dengan lengkap buku-buku PAI K. 13. Menurut penuturan guru PAI yang ada, bahwa distribusi 
buku PAI K. 13 hanya satu kali saja pada tahun 2014 yang disalurkan oleh Disdik setempat. Itupun hanya untuk seluruh peserta didik kelas 1 (satu) dan kelas 4 (empat) saja yang waktu itu berjumlah 194 orang. Sementara untuk kelas 2 (dua) dan kelas 5 (lima) tidak ada sama sekali. Bahkan, hingga kini belum ada pengadaan atau distribusi buku PAI lagi dari pemerintah (Farida Aneta, Guru PAI, wawancara, Senin 9 Maret 2015). Sehingga kebanyakan murid dan termasuk guru PAI hanya men-download dari internet lalu di-print out atau meminjam buku hasil print out itu kemudian difotokopi. Bagi murid-murid yang orang tuanya "mampu", dapat memiliki buku PAI hasil print out atau hasil fotokopi dengan kualitas sebanding dengan buku aslinya (berwarna). Sedangkan bagi murid yang "tidak mampu", mereka hanya menfotokopi seadanya sesuai kemampuan mereka (yang penting ada buku). Demikian halnya dengan buku PAI KTSP yang digunakan oleh peserta didik kelas 3 (tiga) dan kelas (enam) di SDN ini. Karena keterbatasan buku di sekolah, pihak penerbit pernah bekerja sama dengan pihak sekolah melalui koperasi sekolah untuk pengadaan buku-buku termasuk buku PAI untuk dijual kepada peserta didik. Namun, karena adanya regulasi yang dengan tegas melarang pihak sekolah menjual buku kepada peserta didik, akhirnya pihak sekolah menghentikan kegiatan tersebut (Badriyah Podu, wawancara, Jum'at 27 Februari 2015).

Regulasi dimaksud adalah Permendiknas Nomor 2 Tahun 2008 Tentang Buku Pasal 11 yang berbunyi:

Pendidik, tenaga kependidikan, anggota komite sekolah/madrasah, dinas pendidikan pemerintah daerah, pegawai dinas pendidikan pemerintah daerah, dan/atau koperasi yang beranggotakan pendidik dan/atau tenaga kependidikan satuan pendidikan, baik secara langsung maupun bekerjasama dengan pihak lain, dilarang bertindak menjadi distributor atau pengecer buku kepada peserta didik di satuan pendidikan yang bersangkutan atau kepada satuan pendidikan yang bersangkutan, kecuali untuk buku-buku yang hak ciptanya sudah dibeli oleh Departemen, departemen yang menangani urusan agama, dan/atau Pemerintah daerah yakni sebagaimana dimaksud dalam Pasal 3 ayat (4) dan dinyatakan dapat diperdagangkan sebagaimana dimaksud dalam Pasal 8 ayat (1).

Oleh karena itu, Guru PAI hanya bisa menganjurkan kepada orang tua dari peserta didik untuk mengusahakan sendiri buku untuk dimiliki oleh anak mereka. Banyak di antara para orang tua membelikan untuk anak mereka di toko buku. Tidak sedikit juga di antara mereka yang hanya menfotokopi buku yang ada. Sebab, selain harganya mahal jika dibeli di toko buku, buku PAI untuk anak SD termasuk langka atau jumlahnya terbatas di toko buku yang ada di Kota Gorontalo (Farida Aneta, wawancara, Senin 9 Maret 2015).

Mekanisme pengadaan buku PAI, memang masih menjadi "masalah" tersendiri hingga kini. Sebab, kewenangan pengadaan dan distribusi buku PAI di sekolah dasar dianggap tidak berada pada Kementerian Agama meskipun pengawasan pembelajaran PAI di sekolah dasar termasuk kewenangan Kementerian Agama (Burhan Dunggio, Kasi PAI Kementerian Agama Kota Gorontalo, wawancara, Rabu 25 Februari 2015 dan Nur'ani, Staf Bidang PAI Kanwil Kementerian Agama Provinsi Gorontalo, wa- 
wancara, Rabu 25 Februari 2015). Sementara, Kementerian Pendidikan sebagai kementerian yang menaungi sekolah dasar belum juga dapat menyediakan buku PAI (baik KTSP maupun K. 13) dalam bentuk hardcopy secara lengkap (mulai dari kelas satu hingga kelas enam) untuk seluruh sekolah dasar yang ada termasuk di seluruh sekolah dasar di Kota Gorontalo. Bahkan, sejak tahun 2013 baru sekali ada pengadaan buku PAI di SD di Kota Gorontalo. Itupun, khusus untuk K. 13 saja dan hanya untuk kelas 1 (satu) dan 4 (empat) saja. Sementara pengadaan buku PAI KTSP belum ada hingga kini meskipun justru lebih banyak sekolah dasar yang kembali menggunakan KTSP (Wawan Neu, Staf Seksi SD Diknas Kota Gorontalo, wawancara, Rabu 25 Februari 2015). Padahal, dalam Permendiknas Nomor 2 Tahun 2008 Tentang Buku Pasal 3 disebutkan sebagai berikut:

(1) Departemen, Departemen yang menangani urusan agama, Pemerintah Daerah, dan/atau masyarakat mengupayakan tersedianya buku yang bermutu dan sesuai dengan standar nasional pendidikan serta mencukupi kebutuhan pendidik dan peserta didik. (2) Untuk mengupayakan tersedianya buku sebagaimana dimaksud pada ayat (1), Departemen, Departemen Agama, Pemerintah Daerah, dan/atau masyarakat dapat memberikan bantuan dana bagi calon penulis buku dalam bentuk hibah. (3) Penggunaan bantuan dana hibah oleh calon penulis buku sebagaimana dimaksud pada ayat (2) dilaksanakan sesuai perjanjian hibah dan peraturan perundang-undangan. (4) Departemen, Departemen yang menangani urusan agama, dan/atau pemerintah daerah dapat membeli hak cipta buku dari pemiliknya untuk menfasilitasi penyediaan buku bagi pendidik, tenaga kependidikan, dan peserta didik dengan harga yang terjangkau.

Berdasarkan regulasi tersebut, sesungguhnya kewenangan pengadaan buku menjadi tanggungjawab semua pihak tak terkecuali Kementerian Agama (Kemenag). Jadi, bukan hanya menjadi kewenangan Kemendikbud. Bahkan, baik pemerintah daerah maupun masyarakat, pun turut diminta untuk membantu menfasilitasi tersedianya buku-buku pelajaran untuk menjadi pegangan pendidik dan peserta didik di sekolah. Tentu dalam hal ini termasuk buku-buku PAI. Regulasi tersebut sebenarnya memberi peluang seluas-luasnya untuk menfasilitasi pembelajaran khususnya pembelajaran PAI di sekolah dasar. Apalagi, Kementerian Agama merupakan Kementerian yang paling bertanggung jawab dalam pembelajaran PAI. Namun, kemudian terbit Perka LKPP No 10 Tahun 2014 Tentang Pelaksanaan Pengadaan buku Kurikulum 2013 Melalui e-purchasing khususnya pada Bab I Pasal 1 ayat 5 dan 6 disebutkan:

1. Penerus pesanan adalah Petugas yang ditunjuk oleh Kepala Satuan Kerja Perangkat Daerah di tingkat kabupaten/kota yang membidangi urusan Pendidikan yang bertugas untuk meneruskan surat pemesanan dari pembeli.

2. Pembeli adalah Kepala Sekolah/Pejabat yang ditunjuk oleh Kepala Sekolah pada Sekolah Dasar, Sekolah Menengah Pertama, Sekolah Menengah Atas, dan Sekolah Menengah Kejuruan yang bertugas untuk melakukan pemesanan.

Dengan regulasi tersebut, Kementerian Agama akhirnya terbatas kewenangannya dalam pengadaan buku PAI di SD khususnya untuk K.13. 
Pemerintah setempat seharusnya segera "turun tangan" untuk mengatasi persoalan kurangnya atau tidak mencukupinya buku PAI di sekolah dasar dengan memasilitasi pengadaan buku PAI tersebut untuk selanjutnya didistribusikan di seluruh sekolah dasar yang ada. Bila dibiarkan berlarut-larut, tentu dapat berakibat fatal dalam proses penanaman nilai-nilai agama dan budi pekerti terhadap generasi muda di masa akan datang. Sebab, usia anak sekolah dasar merupakan usia yang sangat urgen diberikan pemahaman dasar-dasar agama dan moral secara maksimal yang tentunya mesti difasilitasi juga dengan maksimal terutama dengan penyediaan sarana berupa buku-buku PAI yang sesuai.

Apalagi orang Gorontalo memiliki petuah bijak yang berbunyi "adati hula hula sareati hula hula to kitabullah" (adat bersendi syara' syara' bersendi Kitabullah). Seharusnya petuah ini dapat mengisnpirasi aparat daerah untuk mengupayakan fasilitas yang memadai khususnya buku dalam pembelajaran PAI di sekolah utamanya pada sekolah dasar untuk membentengi sejak awal generasi muda Gorontalo dengan nilainilai agama.

\section{Mekanisme Pemanfaatan Buku PAI di Sekolah Dasar}

Ujian atau ulangan merupakan cara untuk mengetahui kemampuan kognitif peserta didik terkait dengan materi pelajaran yang telah dipelajari. Ketika mendengar kata ujian atau ulangan, bayangan orang pada umumnya adalah kondisi atau suasana ujian tentu tertib, hening atau tenang. Bahkan, ketika ada ujian nasional, biasanya terpampang tulisan "harap tenang ada ujian". Itu sebagai pertanda bagi orang yang tidak terlibat dalam ujian tersebut untuk menghargai peserta ujian yang membutuhkan konsentrasi penuh untuk menjawab pertanyaan ujian. Demikian pula halnya dalam kegiatan ulangan harian atau ujian tulis siswa. Meski tak memakai peringatan seperti itu. Namun, umumnya diketahui bahwa suasananya mesti hening atau tenang dan tertib. Sehingga peserta ujian atau ulangan dapat berkonsentrasi penuh menjawab seluruh pertanyaan dengan baik. Hal itu, ternyata tidak berlaku di semua tempat. Di SDN 30 misalnya, ketika di salah satu kelas sedang berlangsung ulangan harian PAI, suasananya berbanding terbalik dengan apa yang umumnya atau biasanya dilihat pada saat orang menghadapi ujian atau ulangan. Bahkan, beberapa peserta didik terlihat ada yang bercanda, ada yang berlalu lalang, ada yang berlari-lari kecil di sekitar ruangan kelas dan ada bercerita sementara sebagian yang lain sedang mengerjakan soal. Sedangkan buku-buku peserta didik diletakkan di atas meja masing-masing termasuk buku PAI. Dengan kata lain suasananya cukup gaduh. Sementara Guru PAI, tidak menegur sedikitpun mereka yang membuat gaduh itu. Guru PAI hanya mengawasi dengan sesekali berjalan di sekitar mereka yang masih sedang menulis atau menjawab pertanyaan lalu kembali ke tempat duduknya sambil terus mengawasi dan menanti peserta didik yang sudah selesai menjawab pertanyaan ulangan membawa ke hadapannya lembar jawaban. Justru, salah seorang peserta didik teman sekelas mereka yang beragama Budha, memilih berdiri di depan pintu kelas dengan tenang dan tak ingin sedikitpun mengusik teman-temannya yang sedang menghadapi ulangan. Hal itu dilakukannya dengan alasan "kalau duduk di dalam nanti mengganggu 
konsentrasi teman" (Maurine, wawancara, Senin 2 Maret 2015). Letak meja dan kursi juga terlihat tidak seperti letak meja dan kursi di ujian atau ulangan pada umumnya. Letak meja dan kursi diatur seperti letak meja dan kursi ketika sedang diskusi kelompok.

Suasana ulangan peserta didik di kelas tersebut menggambarkan betapa santainya mereka dalam menghadapi ulangan harian.

Menurut Farida Aneta/Guru PAI (wawancara, Selasa 3 Maret 2015) bahwa hanya pada ulangan harian saja kondisinya seperti itu. Itu, disebabkan karena Guru PAI memahami bahwa usia SD memang masanya masih banyak bermain dan ia tidak ingin menekan peserta didiknya agar peserta didik tidak tegang dalam mengikuti pelajaran PAI dan akhirnya tumbuh rasa senang belajar PAI. Apalagi, ia juga sudah mengetahui kapasitas masing-masing peserta didik. Selain itu, sebelum ulangan dimulai ia terlebih dahulu memberi wejangan kepada para peserta ulangan untuk bersikap jujur dan tidak saling menyontek serta bekerja sama dalam menjawab soal ulangan. Ia juga memberi peringatan kepada peserta ulangan bahwa meski mereka menyontek atau bekerja sama, ia dapat mengetahui siapa di antara mereka yang jujur menjawab semua soal karena ia mengawasi mereka dan mengetahui kemampuan mereka masing-masing.

Suasana seperti itu tidak hanya terjadi pada saat ulangan harian. Dalam konteks pembelajaran PAI, suasananya tidak jauh berbeda. Khususnya ketika diberi tugas mengerjakan latihan soal-soal setiap akhir pembelajaran dengan cara diskusi kelompok. Yang berbeda adalah pada saat Guru PAI menjelaskan materi dari buku PAI yang digunakan, suasananya sedikit lebih tenang karena peserta didik memperhatikan apa yang dijelaskan oleh gurunya.

Ini merupakan salah satu strategi yang cukup unik yang diterapkan oleh Guru PAI di SDN 30 Kota Selatan dalam pembelajaran PAI dengan menggunakan buku teks PAI. Untuk menumbuhkan rasa cinta dan senang belajar PAI, diciptakan suasana yang santai namun tetapdengan pengawasan Guru PAIsehingga terbentuk dalam pikiran peserta didik bahwa belajar PAI itu menyenangkan. Hal ini relevan dengan jawaban beberapa peserta didik ketika ditanyakan tentang tanggapan mereka terkait pembelajaran PAI di mana mereka mengaku senang dan suka belajar PAI. Dengan tumbuhnya kecintaan belajar PAI tentu akan dapat membuat peserta didik dengan mudah dapat memahami materi yang terdapat dalam buku PAI yang digunakan. Terbukti dari hasil ujian semester mereka cenderung meningkat setiap tahunnya atau berada pada angka 80 hingga 90 ke atas.

Menurut Farida Aneta (wawancara, Selasa 3 Maret 2015), bahwa dalam ujian tengah semester (UTS) dan ujian akhir semester (UAS), keadaannya lebih tenang dan tertib. Hal itu, memang benar adanya. Ketika UTS dilaksanakan penulis sempat mengamati kondisi yang terjadi di mana keadaannya tenang dan tertib. Tidak seperti ketika ulangan harian. Ini berarti bahwa Guru PAI dan pihak sekolah juga menanamkan kedisiplinan kepada peserta didik melalui UTS dan UAS. 
Strategi lain yang digunakan oleh Guru PAI adalah dengan meminta peserta didik menambah wawasan agama dengan belajar di masjid atau di TPA/TPQ agar mereka dapat membaca dengan lancar materi yang ada di buku PAI utamanya yang berkaitan dengan ayat al-Qur'an atau hadis.

Pembelajaran PAI dengan menggunakan buku PAI di kelas, di SDN 30 memang dilakukan dengan cara ceramah terlebih dahulu dalam arti Guru PAI menjelaskan terlebih dahulu materi yang akan disajikan sampai peserta didik memahami lalu dilakukan pengerjaan tugas atau latihan soal yang ada di dalam buku PAI dengan diskusi kelompok. Selain itu, juga diberikan pekerjaan rumah. Hal itu dilakukan agar peserta didik dapat kembali membaca materi yang telah disajikan atau benar-benar membaca buku PAI yang mereka miliki sehingga dapat dimanfaatkan dengan efektif. Bagi mereka yang tidak memiliki buku PAI atau fotokopi buku PAI, mereka dianjurkan mencatat materi yang telah dipelajari dengan meminjam buku dari teman sekelas (Badriyah Podu, wawancara, Selasa 3 Maret 2015).

Untuk kasus, peserta didik yang tidak memahami suatu materi pembelajaran dari buku PAI yang digunakan di SDN 30, Guru PAI mempersilahkan atau memberi kesempatan peserta didik untuk bertanya di sela-sela pembelajaran baik ketika mereka diskusi maupun ketika Guru PAI sedang menjelaskan suatu materi pembelajaran. Guru PAI, berusaha memberi jawaban sampai mereka benar-benar paham. Selain itu, mereka juga menggunakan alat peraga berupa gambar karakter huruf hijaiyyah khususnya ketika memasuki materi pelajaran tulis menulis huruf hijaiyyah (Badriyah Podu, wawancara, Selasa 3 Maret 2015).

Lain halnya di SDN 7, Guru PAI menerapkan tanya jawab dan dialog sampai mereka paham di kelas 1 (satu) dan 2 (dua)(Zuriyati, wawancara, Sabtu 7 Maret 2015). Sedang untuk kelas 3 (tiga) sampai kelas 6 (enam) ditambahkan dengan metode ceramah dan diskusi sebagaimana yang dilakukan di SDN 30. Namun, karena mayoritas peserta didik di SDN 7 tidak memiliki buku PAI meski dalam bentuk fotokopi sehingga setiap selesai latihan mengerjakan soal-soal dalam bentuk diskusi kelompok Guru PAI mewajibkan peserta didik menulis rangkuman dari materi yang telah dipelajari dengan cara mendiktekan kepada mereka untuk ditulis/dicatat di buku tulis yang mereka miliki.

Salah satu materi yang disenangi peserta didik dari buku PAI yang digunakan adalah materi tentang wudhu dan shalat yang disertai dengan praktek. Praktek dilakukan di Mushalla sekolah yang ada tepat di bagian depan halaman SDN 30. Demikian halnya dengan peserta didik di SDN 7, mereka senang dengan materi tentang wudhu dan shalat yang di dalamnya diberi contoh atau praktek. Hanya saja, karena sarana prasarana yang masih terbatas sehingga praktek shalat hanya mereka lakukan di kelas. Dengan demikian, dapat dikatakan bahwa buku PAI yang digunakan sudah termanfaatkan sebagai mana mestinya dalam menunjang pengetahuan peserta didik dari sisi kognitif dan psikomotor. Namun dari sisi afektif masih terus memerlukan pembinaan. 
Efektifitas pemanfaatan buku termasuk buku PAI tidak hanya terletak pada cara penggunaannya saja tetapi banyak hal terkait sehingga pemanfaatan itu dapat berhasil secara maksimal. Salah satu di antaranya seperti ketika memilih buku yang akan digunakan sebagai acuan utama. Ketika pemilihan buku teks sebagai acuan utama tidak tepat maka bisa dipastikan pembelajaran PAI juga tidak akan sukses.

Mekanisme pemilihan buku teks PAI di Kota Gorontalo dilakukan oleh Guruguru PAI di masing-masing SD yang diusulkan melalui rapat dewan guru. Meski masing-masing Guru PAI sendiri yang mengusulkan di SD tempat tugas mereka, namun ternyata buku teks PAI (khususnya KTSP) yang digunakan di SD se-Kota Gorontalo ternyata seragam. Hal itu, disebabkan karena pada setiap kali Guru-guru PAI melakukan pertemuan dalam wadah kelompok kerja guru (KKG) PAI se-Kota Gorontalo, mereka saling sharing tentang buku teks PAI yang terbaik mutunya untuk digunakan sebagai acuan utama dalam pembelajaran PAI. Adapun, buku teks PAI yang dijadikan sebagai acuan utama itu adalah buku PAI terbitan Erlangga. Sedangkan buku PAI terbitan penerbit lainnya seperti Intan Pariwara dan Yudistira digunakan sebagai penunjang. Sedangkan buku teks PAI untuk yang menerapkan K.13, tidak ditentukan oleh guru PAI sebab sudah ada buku teks PAI K.13 yang ditetapkan oleh pemerintah yang saat ini masih sangat kurang karena distribusinya tidak lancar (Solehan, Ketua KKG Kecamatan Kota Selatan, wawancara, Senin 2 Maret 2015).

Dilihat dari sisi regulasi yang ada terkait dengan pemilihan buku teks yang digunakan maka dapat dikatakan bahwa apa yang dilakukan oleh Guru PAI tersebut di atas relevan dengan Permendiknas Nomor 2 Tahun 2008 Tentang Buku khususnya pada Bab IV Pasal 5 yang berbunyi:

1. Buku teks untuk setiap mata pelajaran yang digunakan pada satuan pendidikan dasar dan menengah dipilih oleh rapat pendidik pada satuan pendidikan dari buku-buku teks pelajaran yang telah ditetapkan kelayakan-pakainya oleh Menteri.

2. Dalam hal Menteri belum menetapkan kelayakan pakai buku teks mata pelajaran tertentu pada satuan pendidikan dasar dan menengah, maka rapat pendidik pada satuan pendidikan dapat memilih buku teks yang tersedia di pasar buku dengan mempertimbangkan mutu buku teks dan kesesuaiannya dengan standar nasional pendidikan.

3. Buku teks untuk mata pelajaran muatan lokal yang digunakan pada satuan pendidikan dasar dan menengah dipilih oleh rapat pendidik pada satuan pendidikan dari buku teks yang ditetapkan kelayakan-pakainnya oleh Gubernur.

4. Dalam hal Gubernur belum menetapkan kelayakan pakai buku teks muatan lokal, maka rapat pendidik pada satuan pendidikan dapat memilih buku teks muatan lokal yang tersedia di pasar buku dengan mempertimbangkan mutu buku teks muatan lokal dan kesesuaiannya dengan standar nasional pendidikan.

SDN 30 sebagai salah satu sekolah dasar piloting untuk K.13 menggunakan 2 (dua) jenis buku PAI yakni buku PAI terbitan Erlangga dan buku teks PAI K.13 yang telah ditentukan oleh pemerintah. Buku teks PAI terbitan Erlangga digunakan untuk SD kelas 3 (tiga) dan 6 (enam). Sedangkan buku teks PAI K.13 digunakan untuk kelas 
1 (satu), 2 (dua), 4 (empat), dan 5 (lima). Di samping itu, untuk pengayaan juga digunakan buku penunjang terbitan Yudistira dan Intan Pariwara (Wirda M. Ali, Guru PAI SDN 30, wawancara, Jum'at 27 Februari 2015).

\section{Kendala dalam Pemanfaatan Buku PAI Sekolah Dasar}

"Kurang buku, pak." Kalimat ini yang pertama terlontar dari semua Guru PAI yang ada di SDN 30 dan SDN 7 Kota Gorontalo ketika ditanyakan tentang problem yang dihadapi tenaga pendidik dan peserta didik dalam melaksanakan pembelajaran PAI di sekolah.

Pada kesempatan lain, salah seorang peserta didik di salah satu sekolah dasar sasaran penelitian suatu ketika menjawab, "Tidak ada buku ibu". Ia menjawab demikian saat salah seorang Guru PAI menanyakan tentang alasan sang peserta didik tidak menjawab salah satu soal dalam UTS PAI yang dilaksanakan serentak pada hari Senin 9 Maret 2015 di Kota Gorontalo.

Dua peristiwa di atas menggambarkan betapa pembelajaran PAI di SD masih terkendala dengan buku. Artinya ketersediaan buku menjadi kendala utama dalam pemanfaatan buku PAI itu sendiri. Saat ini, posisi guru dan pihak sekolah menjadi dilematis terkait dengan ketersediaan buku khususnya buku PAI. Di satu sisi ingin agar buku PAI dimiliki oleh masing-masing peserta didik. Di sisi lain, keterbatasan anggaran sekolah tidak memungkinkan untuk mewujudkan keinginan tersebut. Sementara, untuk memesan buku kepada penerbit lalu dijual kepada peserta didik juga dibatasi regulasi (PermendiknasNomor 2 Tahun 2008 Tentang Buku Pasal 11) yang melarang hal tersebut. Di samping itu, tidak semua peserta didik berasal dari kalangan ekonomi "mampu". Bahkan, untuk menfotokopi pun masih banyak yang tidak sanggup. Hal ini terjadi, di SDN 30 dan SDN 7. Yang paling memprihatinkan lagi adalah di SDN 7, sebab yang memiliki buku PAI hanya 1 (orang) peserta didik di kelas 6 (enam) yang memang orang tuanya termasuk orang yang mampu menyediakan dan memasilitasi anaknya dengan buku-buku sedangkan peserta didik lainnya termasuk kalangan ekonomi lemah (Zuriyati, wawancara, Sabtu 7 Maret 2015).

Untuk mengantisipasi kekurangan buku PAI pegangan peserta didik, Guru PAI menerapkan strategi diskusi kelompok. Di SDN 30 misalnya, dalam pembelajaran PAI, penjelasan materi dilakukan oleh Guru PAI di awal pertemuan sekitar 15 hingga 20 menit kemudian dilakukan diskusi kelompok untuk menjawab latihan soal-soal. Demikian pula yang dilakukan oleh Guru PAI di SDN 7. Hanya saja, karena peserta didik di SDN 7 hampir seluruhnya tidak memiliki buku pegangan PAI, sehingga Guru PAI mendiktekan rangkuman materi setelah diskusi kelompok (di akhir pembelajaran).

Dalam hal materi yang ada di dalam buku PAI yang digunakan pada umumnya tidak mempunyai problem khususnya untuk buku PAI KTSP. Yang dirasakan ada kendala adalah pada K. 13 kelas 1 (satu) di mana sudah diajarkan menulis bahasa arab atau huruf hijaiyyah. Peserta didik di kelas 1 (satu) masih kesulitan memahami hal-hal yang berkaitan dengan bahasa Arab termasuk pelajaran menulis huruf hijaiyyah. Sehingga Guru PAI juga kesulitan mengajarkan materi tersebut pada peserta di- 
diknya. Bagi Guru PAI pelajaran seperti menulis huruf hijaiyyah mestinya diajarkan di kelas IV atau V. Sebab, belum saatnya bagi peserta didik kelas 1 (satu) SD diperkenalkan dengan huruf-huruf arab karena huruf latin (Bahasa Indonesia) saja masih belum lancar. Namun, karena sudah masuk dalam materi PAI kelas 1 (satu), akhirnya harus tetap diajarkan. Untuk itu, Guru PAI berkreasi membuat alat peraga untuk membantu peserta didik memahami materi yang diajarkan. Selain itu, juga dianjurkan untuk belajar di Taman Pendidikan Al-Qur'an terdekat dari rumah mereka (Badriyah Podu, wawancara, Jum'at 27 Februari 2015). Hal ini relevan dengan regulasi tentang pengentasan buta aksara al-Qur'an yang diterbitkan oleh Pemerintah Provinsi Gorontalo Nomor 22 Tahun 2005 Tentang Wajib Baca Tulis Al-Quran bagi siswa yang beragama Islam.

\section{PENUTUP}

\section{Kesimpulan}

Ketersediaan Buku PAI masih sangat terbatas terutama untuk pegangan siswa baik K. 13 maupun KTSP. Hal itu disebabkan belum meratanya pengadaan/distribusi buku ke semua siswa. Selain itu, sebagian siswa tidak mampu membeli atau mengkopi buku yang ada.

Materi dari Buku PAI disampaikan oleh Guru PAI dengan metode Ceramah dan "diskusi kelompok". Selain itu, ada pula setiap akhir pembelajaran rangkuman materi Buku PAI ditulis oleh siswa yang didiktekan langsung oleh Guru PAI. Sedangkan Praktek dari materi Buku PAI, ada yang dilaksanakan di kelas (yang tidak memiliki mushalla) dan di mushalla.

Problem yang dihadapi adalah Sangat Kurangnya Buku PAI untuk Pegangan siswa (K. 13 \& KTSP). Dan dari sisi materi adalah kesulitan murid (khususnya kelas 1) pada materi yang menggunakan bahasa arab pada K.13. kendala guru dalam menerapkan K.13 belum ada sosialisasi K.13 khusus untuk mapel PAI.

\section{Rekomendasi}

Perlu segera pengadaan Buku PAI baik buku wajib maupun buku penunjang di seluruh SD se-Kota Gorontalo yang didistribusikan merata untuk semua guru PAI dan siswa SD se-Kota Gorontalo.

Diperlukan kreatifitas dan inovasi dari guru PAI dalam memanfaatkan buku PAI untuk meningkatkan pengetahuan, pemahaman dan keterampilan siswa terkait materi yang diajarkan, tidak hanya sekedar ceramah dan "diskusi kelompok". Sehingga lebih menyenangkan dan memudahkan bagi siswa dalam memahami semua materi dari buku PAI yang digunakan.

Materi dari buku PAI K.13 masih perlu ditinjau dan formulasi ulang khususnya untuk siswa kelas 1 SD untuk meminimalisir kesulitan siswa dalam memahami materi dari buku PAI yang digunakan. Selain itu, diperlukan segera sosialisasi K. 13 khusus mata pelajaran PAI SD untuk seluruh guru PAI SD se-Kota Gorontalo untuk meningkatkan pengetahuan dan keterampilan mereka dalam mengajarkan PAI serta memudahkan mereka dalam mengimplementasikan K. 13. 


\section{DAFTAR PUSTAKA}

As'ad, M., dkk. (2009). Reformulasi Buku-Buku Paket Madrasah. Makassar: Idelenggara.

Badan Standar Nasional Pendidikan. (2006). Standar Isi Untuk Satuan Pendidikan Dasar dan Menengah. Jakarta.

BAP Provinsi Gorontalo. (2014). Hasil Akreditasi Sekolah / Madrasah Tahun 2007 - 2014 Kota Gorontalo.

BPS Kota Gorontalo. (2014). Gorontalo Dalam Angka Tahun 2014.

Departemen Pendidikan Nasional. (2008). Kamus Besar Bahasa Indonesia (Pusat Bahasa) Edisi Keempat. Jakarta: PT. Gramedia Pustaka Utama.

Dinas Pendidikan Kota Gorontalo. Daftar Analisis Kebutuhan Guru Dinas Pendidikan Kota Gorontalo Tahun Pelajaran 2014 - 2015.

Kementerian Agama Kota Gorontalo. Daftar Guru PAI SD se-Kota Gorontalo Tahun Pelajaran $2014-2015$.

Mayusa, F. (2013). Perbandingan antara Cara Belajar Menggunakan Buku dengan Menggunakan Internet Terhadap Tingkat Konsentrasi Belajar Siswa. Academia.edu.

Milles, M.B., \& Huberman, M.A. (1984). Qualitative Data Analysis. London: Sage Publication.

Muhaimin. (2005). Pengembangan Kurikulum Pendidikan Agama Islam di Sekolah, Madrasah, dan Perguruan Tinggi. Jakarta: PT. RajaGrafindo Persada.

Sugiyono. (2010). Metode Penelitian Pendidikan (Pendekatan Kualitatif, Kuantitatif, dan RED). Bandung: Alfabeta.

Supriadi, D. (2000). Anatomi Buku Sekolah di Indonesia; Problematika Penilaian, Penyebaran, dan Penggunaan Buku Pelajaran, Buku Bacaan dan Buku Sumber. Yogyakarta: Adicita Karya Nusa.

http://www.merdeka.com/peristiwa/ini-kasus-kasus-anak-sd-bunuh-temannya/tewasdikeroyok-tiga-teman-sekolah.html.

Metro TV. https://www.youtube.com/watch?v=FLTYz5qXnNA.

http:// nasional.rimanews.com/kriminal/read/20150309/200680/Tiga-Pelajar-Pelaku-BegalDepok-Diizinkan-Ikut-UN 